\title{
Pentingnya Pembelajaran Kontekstual Untuk \\ Membentuk Karakter Siswa
}

\begin{abstract}
Abstrak:
Wajah buram kini tengah menghiasi dunia pendidikan yang ditandai dengan maraknya sikap dan perilaku siswa yang tidak mencerminkan karakter siswa, seperti tawuran pelajar, dekadensi moral, kurang jujur. Disamping itu masih banyak guru belum optimal melakukan tugas dan fungsinya. Maka dari itu pendidikan memegang peran penting dalam membentuk karakter siswa. Pendidikan karakter merupakan upaya untuk membentuk manusia yang bermoral, beretika dan berakhlak dan cerdas tumbuh dan berkembang sesuai dengan nilai-nilai luhur bangsa dan agama. Untuk itu peran guru sebagai pendidik dengan penuh pengabdian akan menentukan keberhasilan pendidikan karakter. Salah satu upaya untuk membentuk karakter siswa adalah melalui pembelajaran kontekstual. Pembelajaran kontekstual adalah konsep belajar yang membantu guru mengaitkan antara materi yang diajarkan dengan situasi dunia nyata siswa dan mendorong membuat hubungan antara pengetahuan yang dimikinya dengan penerapannya dalam kehidupan sehari-hari dengan melibatkan tujuh komponen utama pembelajaran kontekstual yaitu konstruktivisme, bertanya, inkuiri, masyarakat belajar, permodelan, penilaian autentik.
\end{abstract}

. Pendahuluan

Keberhasilan pembangunan di era global ini sangat ditentukan oleh kualitas sumber daya manusia yang kompetitif dan perwujudan sumber daya manusia yang berkualitas sangat tergantung keberhasilan pelaksanaan pendidikan. Seperti yang tertuang dalam pasal 3 : Pendidikan nasional berfungsi mengembangkan kemampuan dan membentuk watak serta peradaban bangsa yang bermartabat dalam rangka mencerdaskan kehidupan bangsa, bertujuan untuk berkembangnya potensi peserta didik agar menjadi manusia yang beriman dan bertakwa kepada Tuhan Yang Maha Esa, berakhlak mulia, sehat, berilmu, cakap, kreatif, mandiri, dan menjadi warga negara yang demokratis serta bertanggung jawab.(UU No 20 tahun 2003).

Dari tujuan pendidikan nasional tersebut mempunyai makna bahwa potensi yang perlu dikembangkan dari diri siswa bukan hanya aspek kognitip saja namun aspek afektif dan aspek psikomotorik. Dengan kata lain pendidikan nasional juga bertujuan untuk membentuk karakter siswa.

Amanah ini bermaksud agar pendidikan tidak hanya membentuk insan Indonesia yang cerdas, namun juga berkepribadian atau berkarakter, sehingga nantinya akan lahir generasi bangsa yang tumbuh berkembang dengan karakter yang bernafas nilai-nilai luhur bangsa serta agama.

Namun sejak diluncurkan enam tahun lalu, program pendidikan karakter yang diusung pemerintah belum juga menampakkan hasil. Salah satu buktinya, tawuran pelajar kian merajalela. Anggota Komisi X Dewan Perwakilan Rakyat (DPR) Rohmani menegaskan, konsep pendidikan karakter yang digadang-gadang pemerintah masih sebatas teori, bahwa hal tersebut sangat penting bagi Indonesia. Pemerintah pun, kata Rohmani, seharusnya tidak sekadar berteori tentang pendidikan karakter dan membuat program yang jelas dalam membangun karakter generasi muda bangsa.

(Okezone, Senin (1/10/2012).http://kampus.okezone.com/read/2012/10/01/373/697414/pendidikan-karakterpemerintah-jangan-hanya-berteori).

Disamping itu kita juga melihat banyak kejadian yang mencerminkan kondisi rendahnya karakter siswa seperti kurang jujur, dekadensi moral, dan suka nyontek. Dalam angket yang disebar di salah satu SMP negeri di Madiun 
diperoleh hasil yang mencerminkan karakter tidak jujur yaitu 96,72 \% pernah menyontek dan hanya 3,28\% saja yang tidak pernah menyontek.

Hal tersebut ditambah lagi dengan masalah bahwa guru belum bisa sepenuhnya menerapkan tugas dan fungsinya seperti sesuai yang diharapkan undang-undang. Masih banyak guru di sekolah yang menjalankan tugasnya hanya menilai dan mengevaluasi saja, karena tuntutan "keberhasilan" ujian nasional yang celakanya kadang dilakukan dengan cara yang kurang jujur.

Berdasar uraian diatas, tulisan ini mencoba membahas tentang pentingnya pendidikan karakter, guru merupakan tokoh sentral dalam pendidikan karakter, dan pendekatan kontekstual sebagai cara untuk pendekaran karakter.

\section{B. Pembahasan}

\section{Pentingnya pendidikan Karakter}

Pendidikan karakter tidak hanya bertujuan untuk membentuk manusia Indonesia yang bermoral, beretika dan berakhlak, melainkan juga membentuk manusia yang cerdas dan rasional. (Nurla Isna Annilah, 2011)

Muchlas Samani dan Hariyanto menyatakan bahwa karakter dapat dimaknai sebagai nilai dasar yang membangun pribadi seseorang, terbentuk baik karena pengaruh hereditas maupun pengaruh lingkungan, yang membedakannya dengan orang lain, serta diwujudkan dalam sikap dan perilakunya dalam kehidupan sehari-hari(2011). Pendidikan karakter telah menjadi sebuah pergerakan pendidikan yang mendukung pengembangan sosial, pengembangan emosional dan pengembangan etik para siswa.

http://www.berdikarionline.com/editorial/20120703/pentingnya-pendidikan-karakter

Kalau hanya ingin membentuk manusia yang pintar lebih mudah dilakukan, namun membentuk manusia yang berkarakter diperlukan tidak hanya dengan pemberian materi terus ujian, namun perlu contoh, teladan sekaligus praktek dari peserta didik. Hal tersebut seperti pendapat "Ilmu dapat dipelajari oleh segala orang yang cerdas dan tajam otaknya, tetapi manusia yang berkarakter tidak bisa diperoleh begitu saja," kata Bung Hatta. Manusia berkarakter itu meliputi: kecintaan pada kebenaran, berpihak kepada rakyat, siap berjuang demi negara di segala lapangan kehidupan, berfikiran kritis-konstruktif, mengabdi kepada kemanusiaan, dan lain-lain.

Untuk membuat seseorang jadi pintar jauh lebih mudah dan cepat dari pada untuk membuat seseorang jadi baik dan berkarakter. Pintar tidaklah cukup tapi harus dilengkapi juga dengan karakter yang baik. Karakter adalah cara berpikir dan berperilaku yang menjadi ciri khas tiap individu untuk hidup dan bekerjasama, baik dalam lingkup keluarga, masyarakat, bangsa dan negara. Individu yang berkarakter baik adalah individu yang bisa membuat keputusan dan siap mempertanggungjawabkan tiap akibat dari keputusan yang ia buat.

Badan Penelitian dan Pengembangan Kemendiknas mencanangkan pendidikan budaya dan karakter bangsa yang mencakup nilai-nilai Religius, Jujur, Toleransi, Disiplin, Kerja Keras, Kreatif, Mandiri, Demokratis, Rasa Ingin Tahu, Semangat Kebangsaan, Cinta Tanah Air, Menghargai Prestasi, Bersahabat/Komuniktif, Cinta Damai, Gemar Membaca, Peduli Lingkungan, Peduli Sosial, dan Tanggung-jawab. Adapun tujuan pendidikan budaya dan karakter bangsa adalah mengembangkan potensi kalbu/nurani/afektif peserta didik sebagai manusia dan warganegara yang memiliki nilai-nilai budaya dan karakter bangsa, mengembangkan kebiasaan dan perilaku peserta didik yang terpuji dan sejalan dengan nilai-nilai universal dan tradisi budaya bangsa yang religius, Menanamkan jiwa kepemimpinan dan tanggungjawab peserta didik sebagai generasi penerus bangsa, mengembangkan kemampuan peserta didik menjadi manusia yang mandiri, kreatif, berwawasan kebangsaan, mengembangkan 
lingkungan kehidupan sekolah sebagai lingkungan belajar yang aman, jujur, penuh kreativitas dan persahabatan, serta dengan rasa kebangsaan yang tinggi dan penuh kekuatan (dignity). Pencapaian tujuan tersebut akan menjadikan bangsa ini menjadi bangsa yang kuat secara mental, moral dalam mencapai tujuan nasional. Oleh karena itu dalam upaya pembentukan karakter individu/siswa diperlukan kepedulian semua insan yang bertanggungjawab dalam proses pendidikan.

Prinsip yang digunakan dalam pengembangan pendidikan budaya dan karakter bangsa adalah berkelanjutan, melalui semua mata pelajaran (saling menguatkan), muatan lokal, kepribadian, dan budaya sekolah, nilai tidak diajarkan tapi dikembangkan, dan dilaksanakan melalui proses belajar aktif. Pengembangan pendidikan budaya dan karakter bangsa tidak cukup hanya dilakukan hanya dengan salah satu prinsip, namun ke lima prinsip tersebut merupakan satu kesatuan.

Berkelanjutan mengandung makna bahwa proses pengembangan nilai-nilai budaya dan karakter bangsa adalah sebuah proses panjang dimulai dari awal peserta didik masuk sampai selesai dari suatu satuan pendidikan. Sejatinya, proses tersebut dimulai dari kelas satu SD atau tahun pertama dan berlangsung paling tidak sampai kelas 9 atau kelas terakhir SMP. Pendidikan budaya dan karakter bangsa di SMA adalah kelanjutan dari proses yang telah terjadi selama 9 tahun. Demikian seterusnya bahkan sampai tingkat perguruan tinggi pendidikan karakter masih tetap diperlukan.

Melalui semua mata pelajaran, muatan lokal, kepribadian, dan budaya sekolah mensyaratkan bahwa proses pengembangan nilai-nilai budaya dan karakter bangsa dilakukan melalui setiap mata pelajaran, dan dalam setiap kegiatan kurikuler dan ekstra kurikuler. Melekat dalam setiap matapelajaran dimulai dengan pembuatan rencana pembelajaran berkarakter.

Nilai tidak diajarkan tapi dikembangkan mengandung makna bahwa materi nilai-nilai budaya dan karakter bangsa bukanlah bahan ajar biasa. Artinya, nilai-nilai tersebut tidak dijadikan pokok bahasan yang dikemukakan seperti halnya ketika mengajarkan suatu konsep, teori, prosedur, atau pun fakta seperti dalam mata pelajaran agama, bahasa Indonesia, PKn, IPA, IPS, matematika, pendidikan jasmani dan kesehatan, seni, ketrampilan, dan sebagainya. Materi pelajaran biasa digunakan sebagai bahan atau media untuk mengembangkan nilai-nilai budaya dan karakter bangsa. Oleh karena itu guru tidak perlu mengubah pokok bahasan yang sudah ada tetapi menggunakan materi pokok bahasan itu untuk mengembangkan nilai-nilai budaya dan karakter bangsa.

Konsekuensi dari prinsip ini nilai-nilai budaya dan karakter bangsa tidak ditanyakan dalam ulangan ataupun ujian. Walaupun demikian, peserta didik perlu mengetahui pengertian dari suatu nilai yang sedang mereka tumbuhkan pada diri mereka. Mereka tidak boleh berada dalam posisi tidak tahu dan tidak paham makna sebuah nilai.

Proses pendidikan dilakukan peserta didik secara aktif. Prinsip ini menyatakan bahwa proses pendidikan nilainilai budaya dan karakter bangsa dilakukan oleh peserta didik bukan oleh guru. Guru menerapkan prinsip "tut wuri handayani" dalam setiap perilaku yang ditunjukkan peserta didik. Diawali dengan perkenalan terhadap pengertian nilai yang dikembangkan maka guru menuntun peserta didik agar secara aktif (tanpa mengatakan hal ini kepada peserta didik) menumbuhkan nilai-nilai budaya dan karakter pada diri mereka melalui berbagai kegiatan belajar yang terjadi di kelas, sekolah, dan tugas-tugas di luar sekolah. Dari prinsip tersebut tugas dan peran guru menjadi sangat penting dalam mewujudkan karakter anak didik.

2. Guru, tokoh sentral pendidikan

karakter 
Di era global dewasa ini pelaksanaan pendidikan menghadapi banyak tantangan. Bagaimanapun keberhasilan pendidikan merupakan tanggungjawab guru. Menurut Mangunwijaya dalam Firdaus M Yunus pendidikan adalah proses pengembangan pengetahuan dan karakter sikap hidup pada diri manusia dalam arti utuh(2005). Tantangan tersebut mau tidak mau harus dihadapi guru sebagaimana tugas yang harus dilaksanakan sesuai dengan UU no. 14/2005 tentang guru \& dosen - tugas utama guru : Mendidik, Mengajar, Membimbing, Mengarahkan, Melatih, Menilai dan Mengevaluasi peserta didik pada pendidikan anak usia dini jalur pendidikan formal, pendidikan dasar dan pendidikan menengah (ps.1:1)

Mendidik berarti, menanamkan nilai-nilai yang baik menata: hati, pikiran dan sikap mental (harus diawali dari diri sendiri). Mengajar berarti, memberikan pengetahuan/bekal (yang bermanfaat) dalam menghadapi kehidupan. Membimbing berarti, menuntun ke arah tujuan yang telah ditetapkan (harus jelas). Mengarahkan berarti, menunjukkan kepada pilihan yang terbaik. Melatih berarti, membiasakan peserta didik melakukan sesuatu yang baik secara benar dan melakukan sesuatu yang benar secara baik. Menilai dan mengevaluasi berarti, menghitung dan mengukur proses dan hasil kerja kita, apakah tujuan yang ingin kita raih sudah sesuai/tercapai atau belum.

Pendidikan karakter sebenarnya lebih menitikberatkan pada pengalaman daripada sekedar pemahaman, oleh karena itu, melibatkan peserta didik dalam berbagai aktivitas positif dapat membantunya mengenal dan mempelajari kenyataan yang dihadapi.(Nurla Isna Annilah, 2011). Pelayanan yang baik oleh seorang guru berupa kerjasama, pendampingan, dan pengarahan optimal yang merupakan komponen yang diberlakukan secara nyata. Sebab hal itu memberikan kesan positip bagi peserta didik dan mempengaruhi cara berpikir sekaligus karakternya.

Melvin(2006) dalam memulai pelajaran apapun, kita sangat perlu menjadikan siswa aktif semenjak awal. Hal tiu bisa dilakukan dengan susunlah aktivitas pembuka yang menjadikan siswa lebih mengenal satu sama lain, merasa lebih leluasa, ikut berpikir, dan memperhatikan minat terhadap pelajaran. Sedangkan menurut Zubaedi(2011) pendidikan karakter pada dasarnya mencakup pengembangan substansi, proses, dan suasana atau lingkungan yang menggugah, mendorong, dan memudahkan seseorang untuk mengembangkan kebiasaan baik dalam kehidupan sehari-hari. Dalam hal ini guru dituntut lebih profesional dan sekaligus berkarakter. Hal tersebut sesuai dengan pendapat tantangan pendidikan yang amat kompleks itu menuntut guru-guru yang mempunyai karakter dan sifat tertentu seperti menjalankan tugasnya sebagai panggilan hidup, berdedikasi tinggi, demokratis, profesional, dan bersikap sebagai seorang intelektual. (Paul Suparno dalam Tony D Widiastono, 2004).

Syaiful Bahri Djamarah(2010) menjadi guru berdasarkan pekerjaan adalah suatu perbuatan yang mudah, tetapi menjadi guru berdasarkan panggilan jiwa atau tuntutan hati nurani adalah tidak mudah, karena kepadanya lebih banyak dituntut suatu pengabdian kepada peserta didik daripada karena tuntutan pekerjaan dan material oriented. Guru yang mendasarkan pengabdiannya karena panggilan jiwa merasakan jiwanya lebih dekat dengan anak didiknya. Ketiadaan anak didiknya di kelas menjadi pemikirannya, karena anak didiknya tidak hadir di kelas, apa yang menyebabkannya, dan berbagai pertanyaan yang mungkin guru ajukan ketika itu.

Kebaikan seorang guru tercermin dari peribadiannya dalam bersikap dan berbuat, tidak saja ketika di sekolah, tetapi juga di luar sekolah. Guru memang harus menyadari bahwa dirinya adalah figur yang diteladani oleh semua pihak terutama oleh anak didiknya di sekolah. Guru adalah bapak rohani bagi anak didiknya. Hal ini berarti, bahwa guru sebagai arsitek bagi rohani anak didiknya. Kebaikan rohani anak didiknya tergantung dari pembinaan dan bimbingan guru. Di sini tugas dan tanggungjawab guru adalah meluruskan tingkah laku dan perbuatan anak didik yang kurang baik, yang dibawanya dari lingkungan keluarga dan masyarakat. Oleh karena itu dalam menjalankan tugasnya, guru juga harus berpedoman pada kode etik guru :

Guru berbakti membimbing anak didik seutuhnya untuk membentuk manusia pembangunan yang berPancasila.

Guru memiliki kejujuran profesional dalam menerapkan kurikulum sesuai kebutuhan anak didik. 
Guru mengadakan komunikasi, terutama dalam memperoleh info tentang anak didik, tapi menghindarkan diri dari segala bentuk penyalahgunaan.

Guru mencptakan suasana kehidpan sekolah dan memelihara hubungan dengan orang tua anak didik sebaik-baiknya bagi kepentingan anak didik.

Guru memelihara hubungan baik dengan masyarakat di sekitar sekolah maupun masyarakat yang lebih luas untuk kepentingan pendidikan.

Guru sendiri atau bersama-sama berusaha mengembangkan dan meningkatkan mutu profesinya.

Guru menciptkan dan memelihara hubungan antara sesama guru, baik berdasarkan lingkungan kerja maupun dalam hubungan keseluruhan.

Guru secara hukum bersama-sama memelihara, membina dan meningkatkan mutu organisasi guru profesi sebagai sarana pengabdiannya.

Guru melaksanakan segala ketentuan yang merupakan kebijaksanaan pemerintah dalam bidang pendidikan. (YPLP/PPLP PGRI Pusat, 2011)

Implementasi pelaksanaan tugas guru harus dapat melaksanakan kompetensi yang dimiliki seorang guru. Guru merupakan sosok digugu dan ditiru, oleh karena itu dalam melaksanakan tugasnya guru harus mendasarkan pada kode etik guru.

3. konstekstual

Paradigma pendidikan Indonesia saat ini adalah ingin membangun manusia seutuhnya sehingga proses pendidikan mengarah pada empat macam olah, yaitu: pertama potensi olah hati, kedua olah pikir, ketiga olah rasa dan ke empat olah raga.(Ondi Saondi dan Aris Suherman, 2010). Ke empat macam olah tersebut perlu diseimbangkan agar potensi anak didik dapat keluar, dikembangkan dan dibentuk agar potensi tersebut dapat terwujud secara utuh dalam bentuk karakter yang kuat.

Secara psikologis, perilaku berkarakter merupakan perwujudan dari potensi Intelligence Quotient (IQ), Emotional Quotient (EQ), Spiritual Quotient (SQ), dan Adverse Quotient (AQ) yang dimiliki oleh seseorang. Konfigurasi karakter dalam konteks totalitas proses psikologis dan sosio-kultural pada akhirnya dapat dikelompokkandalam empat kategori, yakni

1) olah hati (spiritual and emotional development); 2) olah pikir (intellectual development); 3) olah raga dan kinestetik (physical and kinestetic development); dan 4) olah rasa dan karsa (affective and creativity development). Keempat proses psiko-sosial ini secara holistik dan koheren saling terkait dan saling melengkapi dalam rangka pembentukan karakter dan perwujudan nilai-nilai luhur dalam diri seseorang (Kemdiknas, 2010).

Sedangkan Menurut Timothy Wibowo Dari penelitian diberbagai belahan dunia yang terus berkembang, hasil riset tentang tehnik penyerapan informasi ke otak dibagi menjadi 5 tahap :

Membaca dengan prosentase penyerapan informasi $10 \%$

Mendengar dengan prosentase penyerapan informasi $20 \%$

Mendengar dan Melihat dengan prosentase penyerapan informasi 50\% 
Mengatakan dengan prosentase penyerapan informasi $70 \%$

Mengatakan dan melakukan dengan prosentase penyerapan informasi 90\% (http://www.pendidikankarakter.com/siapakah-guru-pendidikan-karakter)

Dari pendapat-pendapat tersebut di atas, kiranya akan sangat tepat jika untuk mengeksplorasi potensi yang dimiliki oleh anak didik dalam mewujudkan karakter yang baik digunakan dengan pendekatan atau pembelajaran kontekstual.

Pembelajaran kontekstual menyajikan suatu konsep yang mengaitkan materi pelajaran yang dipelajari siswa dengan konteks dimana materi tersebut digunakan, serta berhubungan dengan bagaimana seseorang belajar atau gaya/cara siswa belajar. Konteks memberikan arti, relevansi, dan manfaat penuh terhadap belajar.

Pendekatan konstekstual berlatar belakang bahwa siswa belajar lebih bermakna dengan melalui kegiatan mengalami sendiri dalam lingkungan alamiah, tidak hanya sekedar mengetahui, mengingat, dan memahami. Pembelajaran tidak hanya berorientasi target penguasaan materi, yang akan gagal dalam membekali siswa untuk memecahkan masalah dalam kehidupannya. Dengan demikian proses pembelajaran lebih diutamakan daripada hasil belajar, sehingga guru dituntut untuk merencanakan strategi pembelajaran yang variatif dengan prinsip membelajarkan - memberdayakan siswa, bukan mengajar siswa.

(http://smacepiring.wordpress.com/2008/02/19/pendekatan-dan-metode-pembelajaran/).

Trianto (2009) Pembelajaran kontekstual adalah konsep belajar yang membantu guru mengaitkan antara materi yang diajarkan dengan situasi dunia nyata siswa dan mendorong siswa membuat hubungan antara pengetahuan yang dimilikinya dengan penerapannya dalam kehidupan mereka sehari-hari, dengan melibatkan tujuh komponen utama pembelajaran kontekstual yaitu: konstruktivisme, bertanya, inkuiri, masyarakat belajar, pemodelan dan penilaian autentik.

Menurut Fahmi Riadi Pendidikan karakter masuk kelas, itu memang seharusnya. Lebih dari itu, ia juga harus ditanamkan melalui kegiatan-kegiatan pembiasaan yang pelaksanaannya baik dilakukan secara spontan, terencana, maupun melalui keteladanan. Perlu diingat kembali pepatah tersebut di atas, bahwa sumber perilaku itu adalah pikiran. Dari mana pikiran itu tercipta, bisa melalui proses abstraksi dari apa yangdilihat, hubungan pergaulan yang dirasa, dan pengetahuan yangdidengar dari guru-guru.

(http://edukasi.kompasiana.com/2012/07/31/pendidikan-karakter/)

Komalasari (2011) mengidentifikasi karakteristik pembelajaran kontekstual meliputi pembelajaran yang menerapkan konsep keterkaitan(relating), konsep pengalaman langsung(experiencing), konsep aplikasi, konsep kerjasama(cooperating), konsep pengaturan diri(self-regulatif), dan konsep penilaian autentik (autenthic assessmen).

Menurut Depdiknas(2010) untuk penerapannya, pendekatan kontektual (CTL) memiliki tujuh komponen utama, yaitu konstruktivisme(constructivism), menemukan (Inquiry), bertanya (Questioning), masyarakat-belajar (Learning Community), pemodelan (modeling), refleksi (reflection), dan penilaian yang sebenarnya (Authentic).

Dari pendapat di atas, pelaksanaan pembelajaran kontekstual dapat berjalan dengan baik jika dapat menerapkan komponen konstruktivisme(constructivism), konsep keterkaitan termasuk bertanya, konsep pengalaman langsung inkuiri, kerjasama/masyarakat belajar, aplikasi/pemodelan, pengaturan diri/refleksi dan penilaian autentik. 
Kontruktivisme merupakan landasan berpikir CTL, yang menekankan bahwa belajar tidak hanya sekedar menghafal, mengingat pengetahuan tetapi merupakan suatu proses belajar mengajar dimana siswa sendiri aktif secara mental mebangun pengetahuannya, yang dilandasi oleh struktur pengetahuan yang dimilikinya. Konstruktivistis menekankan pentingnya siswa membangun sendiri pengetahuan mereka lewat keterlibatan aktif proses belajar mengajar. Proses belajar mengajar lebih diwarnai student centered daripada teacher centered. Sebagaian waktu proses belajar mengajar berlangsung dengan berbasis pada aktivitas siswa. Siswa tidak sekedar duduk dan mendengarkan apa yang disampaikan guru, namun diarahkan untuk dapat lebih aktif, kreatif dan berpartisipasi dalam proses pembelajaran.

Dalam penerapan konstruktivisme tersebut guru bertugas untuk memfasilitasi proses tersebut dengan : menjadikan pengetahuan bermakna dan relevan bagi siswa, memberi kesempatan siswa menemukan dan menerapkan idenya sendiri, dan menyadarkan siswa agar menerapkan strategi mereka sendiri dalam belajar. Dengan proses tersebut sekaligus sebenarnya sudah mendorong siswa untuk dapat menerapkan konsep keterkaitan.

Pembelajaran yang menerapkan konsep keterkaitan(relating) adalah proses pembelajaran yang memiliki keterkaitan relevansi dengan bekal pengetahuan yang telah ada pada diri siswa dengan konteks pengalaman dalam kehidupan dunia nyata siswa. Dalam konsep ini diharapkan siswa dapat menerapkan keterkaitan materi pelajaran dengan pengetahuan dan keterampilan sebelumnya, materi lain dalam matapelajaran PKn, matapelajaran lain, konteks keluarga, pengalaman dunia nyata, kebutuhan siswa, dan materi dari terbatas ke kompleks dan dari konkret ke abstrak. Dalam penerapan konsep keterkaitan, penerapan bertanya merupakan strategi utama yang berbasis kontekstual. Bertanya dalam pembelajaran dipandang sebagai kegiatan guru untuk mendorong, membimbing, dan menilai kemampuan berpikir siswa. Bagi siswa, kegiatan bertanya merupakan bagian penting dalam melaksanakan pembelajaran yang berbasis inquiry yaitu menggali informasi, mengkonfirmasikan apa yang sudah diketahui, dan mengarahkan perhatian pada aspek yang belum diketahuinya. Sehingga dalam proses tersebut dapat membentuk pola pikir siswa untuk memahami masalah, merangsang untuk bertanya serta mendeskripsikan/merangkum dalam bentuk sebuah pertanyaan.

Dalam sebuah pembelajaran yang produktif, kegiatan bertanya berguna untuk : menggali informasi, mengecek pemahaman siswa, membangkitkan respon kepada siswa, mengetahui sejauh mana keingintahuan siswa, mengetahui hal-hal yang sudah diketahui siswa, memfokuskan perhatian siswa pada sesuatu yang dikehendaki guru, membangkitkan lebih banyak lagi pertanyaan dari siswa, dan menyegarkan kembali pengetahuan siswa. (115). Pengetahuan yang dimiliki seseorang selalu dimulai dari bertanya. Bertanya merupakan strategi utama pembelajaan berbasis kontekstual. Kegiatan bertanya berguna untuk : 1) menggali informasi, 2) menggali pemahaman siswa, 3) membangkitkan respon kepada siswa, 4) mengetahui sejauh mana keingintahuan siswa, 5) mengetahui hal-hal yang sudah diketahui siswa, 6) memfokuskan perhatian pada sesuatu yang dikehendaki guru, 7) membangkitkan lebih banyak lagi pertanyaan dari siswa, 8) untuk menyegarkan kembali pengetahuan siswa. Jadi dengan pemahaman dan respon siswa akan diketahui fokus perhatian dan semangat siswa untuk dapat menerapkan konsep keterkaitan. Dalam penerapan konsep ini siswa sekaligus dituntut untuk berpikir secara komprehensip dalam arti bahwa setiap masalah selalu berkaitan dengan masalah lain atau hal-hal lain.

Dalam proses menerapkan konsep keterkaitan, diharapkan siswa dapat memahami, melaksanakan, dan mewujudkan karakter Rasa Ingin Tahu, Kerja Keras, Gemar Membaca, Kreatif, Mandiri, Menghargai Prestasi, Bersahabat/Komunikatif, Religius, Jujur, Toleransi, Disiplin, Demokratis, Cinta Damai, Peduli Lingkungan, Peduli Sosial, dan Tanggung-jawab

Pembelajaran yang menerapkan konsep pengalaman langsung adalah proses pembelajaran yang memberikan kesempatan pada siswa untuk mengonstruksi pengatahuan dengan cara menemukan dan mengalami sendiri secara langsung. Inkuiri merupakan bagian inti dari kegiatan pembelajaran berbasis kontekstual. Pengetahuan yang diperoleh siswa diharapkan bukan hasil mengingat seperangkat fakta-fakta, tetapi hasil dari menemukan sendiri. Guru harus selalu merancang kegiatan yang merujuk pada kegiatan menemukan, apapun materi yang diajarkan. 
Siswa tidak hanya memperoleh teori-teori saja namun sekaligus juga dapat melihat teori tersebut dalam bentuk fakta di lapangan.

Menemukan merupakan bagaian inti dari kegiatan pembelajaran berbasis kontekstual Karena pengetahuan dan keterampilan yang diperoleh siswa diharapkan bukan hasil mengingat seperangkat fakta-fakta tetapi hasil dari menemukan sendiri. Kegiatan menemukan(inquiry) merupakan sebuah siklus yang terdiri dari observasi(observation), bertanya (questioning), mengajukan dugaan (hiphotesis), pengumpulan data (data gathering), penyimpulan (conclusion). Dalam konsep ini diharapkan siswa dapat menerapkan konsep pengalaman langsung meliputi eksplorasi, penemuan, investigasi, penemuan dan pemecahan masalah. Dengan menerapkan pengalaman langsung, diharapkan siswa dapat memahami, melaksanakan, dan mewujudkan karakter Kreatif, Mandiri, Demokratis, Rasa Ingin Tahu, Bersahabat/Komuniktif, Cinta Damai, Gemar Membaca, Peduli Lingkungan, Peduli Sosial, dan Tanggung-jawab.

Proses pembelajaran menerapkan konsep aplikasi adalah proses pembelajaran yang menekankan pada penerapan fakta, konsep, prinsip, dan prosedur yang dipelajari dalam situasi dan konteks lain yang berbeda sehingga bermanfaat bagi kehidupan siswa. Dalam konsep ini diharapkan siswa dapat menerapkan konsep aplikasi yang meliputi penerapan materi yang telah dipelajri dalam lingkungan keluarga, sekolah, masyarakat, penerapan materi dalam memecahkan masalah, pembelajaran pelayanan dan lain-lain. Dalam proses aplikasi ini tidak sekedar dapat dilakukan atau ditularkan oleh guru namun dapat dilakukan oleh orang lain/sumber lain termasuk siswa karena Pemodelan pada dasarnya membahasakan yang dipikirkan, mendemonstrasi bagaimana guru menginginkan siswanya untuk belajar dan malakukan apa yang guru inginkan agar siswanya melakukan. Dalam pembelajaran kontekstual, guru bukan satu-satunya model. Model dapat dirancang dengan melibatkan siswa dan juga mendatangkan dari luar.

Jika konsep ini bisa dijalankan, diharapkan siswa dapat memahami, melaksanakan dan mewujudkan semua karakter yang diharapkan yaitu Religius, Jujur, Toleransi, Disiplin, Kerja Keras, Kreatif, Mandiri, Demokratis, Rasa Ingin Tahu, Semangat Kebangsaan, Cinta Tanah Air, Menghargai Prestasi, Bersahabat/Komuniktif, Cinta Damai, Gemar Membaca, Peduli Lingkungan, Peduli Sosial, dan Tanggung-jawab

Pembelajaran yang menerapkan kerjasama adalah pembelajaran yang mendorong kerjasama di santara siswa, antara siswa dengan guru dan sumber belajar. Indicator pembelajaran yang menerapkan kerjasama diharapkan siswa dapat kerja kelompok dalam memecahkan masalah dan mengerjakana tugas, saling bertukar pikiran, mengajukan dan menjawab pertanyaan, komunikasi interaktif antar semua siswa, antara siswa dengan guru, siswa dengan nara sumber, dan menghormati perbedaan gender, suku, ras, agama, status social ekonomi, budaya dan perspektif.

Konsep masyarakat belajar menyarankan agar hasil pembelajaran diperoleh dari kerjasama dengan orang lain. Masyarakat belajar bisa terjadi apabila ada poses komunikasi dua arah. Dalam masyarakat belajar, dua kelompok atau lebih terlibat dalam komunikasi pembelajaran saling belajar satu sama lain. Adanya komunikasi yang multi arah bisa memacu anak atau peserta didik untuk lebih termorivasi dalam mengeksplorasi potensi yang dimiliki. Dalam proses ini diharapkan siswa dapat memahami, melaksanakan, dan mewujudkan karakter Jujur, Demokratis, Tanggung-jawab, Toleransi, Disiplin, Kerja Keras, Kreatif, Mandiri, Rasa Ingin Tahu, Menghargai Prestasi, Bersahabat/Komuniktif, Cinta Damai, Gemar Membaca, Peduli Lingkungan, dan Peduli Sosial.

Pembelajaran yang menerapkan konsep pengaturan diri adalah pembelajaran yang mendorong siswa untuk mengatur diri dan pembelajarannya secara mandiri. Indikatornya siswa dapat memiliki motovasi belajar sepanjang hayat, motivasi untuk mencari dan menggunakan informasi dengan kesadaran sendiri, melaksanakan prinsip trialerror, melakukan refleksi dan belajar mandiri. 
Refleksi Adalah cara berpikir tentang apa yang baru dipelajari atau berpikir ke belakang tentang apa-apa yang sudah kita lakukan di masa lalu. Siswa mengendapkan apa yang baru dipelajarinya sebagai struktur pengetahuan yang baru, yang merupakan pengayaan atau revisi dari pengetahuan sebelumnya. Refleksi merupakan respons terhadap kejadian, aktivitas, atau pengetahuan yang baru diterima. Refleksi merupakan cara berpikir atau respon tentang apa yang baru dipelajari aau berpikir kebelakang tentang apa yang sudah dilakukan dimasa lalu. Realisasinya dalam pembelajaran, guru menyisakan waktu sejenak agar siswa melakukan refleksi yang berupa pernyataan langsung tentang apa yang diperoleh hari itu.

Dalam proses ini diharapkan siswa dapat memahami, melaksanakan, dan mewujudkan karakter Rasa Ingin Tahu, Religius, Jujur, Toleransi, Disiplin, Kerja Keras, Kreatif, Mandiri, Demokratis, Semangat Kebangsaan, Cinta Tanah Air, Menghargai Prestasi, Bersahabat/Komuniktif, Cinta Damai, Gemar Membaca, Peduli Lingkungan, Peduli Sosial, dan Tanggung-jawab.

Pembelajaran yang menerapkan konsep Assesment autentik adalah pembelajaran yang mengukur, memonitor, dan menilai semua aspek hasil belajar (yang mencakup dalam domain kognitif, afektif dan psikomotorik), baik yang Nampak sebagai hasil akhir suatu proses pembelajaran maupun berupa perubahan dan perkembangan aktivitas, dan perolehan belajar selama proses pembelajaran di kelas ataupun di luar kelas. Dengan demikian penilaian pembelajaran utuh menyeluruh dalam aspek kognitif, afektif, dan psikomotorik, serta dalam keseluruhan tahapan proses pembelajaran(di awal, tengah dan dia akhir).

Penilaian adalah proses pengumpulan berbagai data yang bisa memberi gambaran mengenai perkembangan belajar siswa. Dalam pembelajaran berbasis CTL, gambaran perkembangan belajar siswa perlu diketahui guru agar bisa memastikan bahwa siswa mengalami pembelajaran yang benar. Fokus penilaian adalah pada penyelesaian tugas yang relevan dan kontekstual serta penilaian dilakukan terhadap proses maupun hasil. Dalam proses penialain ini diharapkan siswa dapat memahami, melaksanakan, dan mewujudkan karakter jujur, Jujur, Toleransi, Disiplin, Kerja Keras, Kreatif, Mandiri, Demokratis, Rasa Ingin Tahu, Menghargai Prestasi, Bersahabat/Komuniktif, Cinta Damai, Gemar Membaca, Peduli Lingkungan, Peduli Sosial, dan Tanggung-jawab

\section{Penutup}

Karakter adalah cara berpikir dan berperilaku yang menjadi ciri khas tiap individu untuk hidup dan bekerjasama, baik dalam lingkup keluarga, masyarakat, bangsa dan negara. Individu yang berkarakter baik adalah individu yang bisa membuat keputusan dan siap mempertanggungjawabkan tiap akibat dari keputusan yang ia buat.

Prinsip yang digunakan dalam pengembangan pendidikan budaya dan karakter bangsa adalah berkelanjutan, melalui semua mata pelajaran (saling menguatkan), muatan lokal, kepribadian, dan budaya sekolah, nilai tidak diajarkan tapi dikembangkan, dan dilaksanakan melalui proses belajar aktif. Dari prinsip tersebut, pendekatan yang bisa ditawarkan adalah dengan pendekatan kontekstual yang mencakup tujuh komponen utama, yaitu konstruktivisme (constructivism), menemukan (Inquiry), bertanya (Questioning), masyarakat-belajar (Learning Community), pemodelan(modeling), refleksi (reflection), dan penilaian yang sebenarnya (Authentic). 


\section{Daftar Pustaka}

Abdul Majid \& Dian Andayani, 2011, Pendidikan karakter Persepektif Islam, Bandung : PT Remaja Rosdakarya.

Firdaus M Yunus, 2004, Pendidikan Berbasis Realitas-Paulo Freire \& YBMangunwijaya, Jogyakarta : Logung Pustaka.

Hanafiah dan Cucu Suhana, 2012, Konsep Strategi Pembelajaran, Bandung : PT Refika Aditama.

Kementrian Pendidikan Nasional, 2010. Pendidikan Karakter di SMP, Ditjen Mandikdasmen Direktorat pembinaan SMP

Kokom Komalasari, 2011, Pembejalaran Kontekstual, konsep dan Aplikasi, Bandung: PT Refika Aditama.

Lembaga Pendidikan, Jakarta : Kencana Prenada Group.

Melvin L Silberman (terjemahan Raisul Muttaqien) 2006, Active Learning: 100 Cara belajar Siswa Aktif, Bandung: Nusamedia dan Nuansa

Muchlas Samani \& Hariyanto, 2011, Konsep dan Model Pendidikan Karakter, Bandung : PT Remaja Rosdakarya.

Nurla Isna Aunillah, 2011, Panduan Menerapkan Pendidikan Karakter di Sekolah,. Jogyakarta : Laksana

Trianto, 2009, Mendesain Model Pembelajaran Inovatif-Progresif, Jakarta: Kencana Prenada Media Group.

Ondi Saondi dan Aris Suherman, 2010, Etika Profesi Keguruan, Bandung : PT Refika Aditama.

Syaiful Bahri Djamarah, 2010, Guru dan Anak Didik Dalam Interaksi Edukatif, Jakarta :PT Rineka Cipta.

Tonny D. Widiastono, 2004, Pendidikan Manusia Indonesia, Jakarta : PT Kompas Media Nusantara.

YPLP/PPLP PGRI Pusat, 2011. Pendidikan Sejarah Perjuangan dan Jatidiri PGRI.

Zainal Arifin, 2009, Evaluasi Pembelajaran, Bandung : PT Remaja Rosdakarya

Zubaedi, 2011, Desain Pendidikan Karakter:Konsepsi dan Aplikasinya Dalam 